\title{
PEP-1-glutaredoxin 1 protects against hippocampal neuronal cell damage from oxidative stress via regulation of MAPK and apoptotic signaling pathways
}

\author{
EUN JI RYU ${ }^{1 *}$, DAE WON KIM ${ }^{2 *}$, MIN JEA SHIN ${ }^{1 *}$, HYO SANG JO ${ }^{1}$, JUNG HWAN PARK ${ }^{1}$, \\ SU BIN CHO ${ }^{1}$, CHI HERN LEE ${ }^{1}$, HYEON JI YEO ${ }^{1}$, EUN JI YEO ${ }^{1}$, YEON JOO CHOI ${ }^{1}$, DUK-SOO KIM ${ }^{3}$, \\ SUNG-WOO CHO ${ }^{4}$, YONG-JUN CHO ${ }^{5}$, EUN JEONG SOHN ${ }^{1}$, ORA SON ${ }^{1}$, \\ KEUN WOOK LEE ${ }^{1}$, KYU HYUNG HAN ${ }^{1}$, JINSEU PARK ${ }^{1}$, WON SIK EUM ${ }^{1}$ and SOO YOUNG CHOI ${ }^{1}$ \\ ${ }^{1}$ Department of Biomedical Science and Research Institute of Bioscience and Biotechnology, Hallym University, \\ Chuncheon, Gangwon 24252; ${ }^{2}$ Department of Biochemistry and Molecular Biology, Research Institute of Oral Sciences, \\ College of Dentistry, Gangneung-Wonju National University, Gangneung, Gangwon 25457; ${ }^{3}$ Department of Anatomy, \\ College of Medicine, Soonchunhyang University, Cheonan-Si, South Chungcheong 31538; ${ }^{4}$ Department of Biochemistry and \\ Molecular Biology, University of Ulsan College of Medicine, Seoul 05505; ${ }^{5}$ Department of Neurosurgery, \\ Hallym University Medical Center, Chuncheon, Gangwon 24253, Republic of South Korea
}

Received June 6, 2017; Accepted January 11, 2018

DOI: $10.3892 / \mathrm{mmr} .2018 .9176$

\begin{abstract}
Oxidative stress is known to be a primary risk factor for neuronal diseases. Glutaredoxin (GLRX)-1, a redox-regulator of the thioredoxin superfamily, is known to exhibit an important role in cell survival via various cellular functions. However, the precise roles of GLRX1 in brain ischemia are still not fully understood. The present study investigated whether transduced PEP-1-GLRX1 protein has protective effects against oxidative stress in cells and in an animal model. Transduced PEP-1-GLRX1 protein increased HT-22 cell viability under oxidative stress and this fusion protein significantly reduced intracellular reactive oxygen species and levels of DNA damage.In addition, PEP-1-GLRX1 protein regulated $\mathrm{RAC}-\mathrm{a}$ serine/threonine-protein kinase and mitogen-activated protein kinase signaling, in addition to apoptotic signaling including B cell lymphoma (Bcl)-2, Bcl-2 associated X, apoptosis regulator, pro-caspase- 9 and p53 expression levels. In an ischemic animal model, it was verified that PEP-1-GLRX1 transduced into the Cornu
\end{abstract}

Correspondence to: Dr Won Sik Eum or Dr Soo Young Choi, Department of Biomedical Science and Research Institute of Bioscience and Biotechnology, Hallym University, 1 Hallymdaehak Gil, Chuncheon, Gangwon 24252, Republic of South Korea

E-mail:wseum@hallym.ac.kr

E-mail: sychoi@hallym.ac.kr

*Contributed equally

Key words: ischemia, PEP-1-glutaredoxin 1, oxidative stress, apoptosis, protein therapy
Ammonis 1 region of the animal brain, where it markedly protected against ischemic injury. These results indicate that PEP-1-GLRX1 attenuates neuronal cell death resulting from oxidative stress in vitro and in vivo. Therefore, PEP-1-GLRX1 may exhibit a beneficial role in the treatment of neuronal disorders, including ischemic injury.

\section{Introduction}

Oxidative stress is known to be a result of excessive levels of reactive oxygen species (ROS) including hydroxyl radicals, superoxide anions, and hydrogen peroxide, which are produced by cellular respiration in mitochondria and other cellular process. ROS is known to be associated with the pathogenesis of various diseases (1-3). Oxidative stress is associated with cell signaling and gene regulation systems in a number of molecular biological processes. Excessive ROS levels have resulted in various diseases via the dysfunction of cellular macromolecules, leading to the promotion of lipid peroxidation, DNA fragmentation, and protein damage, eventually resulting in cell death $(4,5)$. Several studies have suggested that the regulation of intracellular ROS levels is very important to neuronal cell survival in various diseases $(6,7)$.

Human glutaredoxin (GLRX)-1 is a member of the thioredoxin family, additionally termed glutathione (GSH)-dependent thiol oxidoreductase, and is a small molecular weight $(12 \mathrm{kDa})$ protein (8). GLRX1 is distributed in various human tissues including the brain, which are involved in sulfhydryl homeostasis and exhibit roles in the regulation of redox signaling, and control a variety of cellular processes (9-11). A previous study demonstrated that GLRX1 has an important role as a ROS scavenger and protects against protein oxidation resulting from oxidative stress (12). However, the exact function of GLRX1 in ischemic injury remains to be fully elucidated. 
In general, it is difficult for exogenous macromolecules to transduce into cells. Protein transduction domains (PTDs) or cell penetrating peptides (CPPs) consist of a short chain of amino acids, and effectively transduce exogenous macromolecules into cells and tissues (13). Of the various PTDs, PEP-1 peptide has several advantages including rapid transduction of proteins, high stability in physiological buffers, and high efficiency of transduction $(14,15)$. Although the precise transduction mechanism is not clear yet, it has been demonstrated that a variety of therapeutic PTD fused proteins were successfully delivered into various cells in vitro and in in vivo animal models, transduced proteins effectively prevented cell death (16-22). The present study investigated whether PEP-1-GLRX1 protein has protective effects against oxidative stress in HT-22 cells and against ischemic brain injury in an animal model. It was revealed that transduced PEP-1-GLRX1 protein has protective effects against oxidative stress in HT-22 cells and in an animal model of ischemia.

\section{Materials and methods}

Materials and cell culture. $\mathrm{Ni}^{2+}$-nitrilotri-acetic acid Sepharose Superflow was purchased from Qiagen, Inc. (Valencia, CA, USA). Histidine antibody was obtained from Santa Cruz Biotechnology, Inc. (Dallas, TX, USA). B-cell lymphoma 2 (Bcl-2) antibody was obtained from Abcam (Cambridge, UK). Phosporylated (p)-protein kinase B (Akt), Akt, p-mitogen-activated protein kinase 8 (JNK), JNK, p-p44/42 mitogen-activated protein kinase (ERK), ERK, p-mitogen activated protein kinase 14 (p38), p38, p-cellular tumor antigen p53 (p53), p53, Bcl-2 associated protein $\mathrm{X}$ (Bax), caspase-9 and $\beta$-actin primary antibodies were obtained from Cell Signaling Technology, Inc. (Danvers, MA, USA). 2',7'-Dichlorofluorescein diacetate (DCF-DA) was purchased from Sigma-Aldrich (Merck KGaA, Darmstadt, Germany). 8-hydroxy-2-deoxyguanosine (8-OHdG) antibodies were purchased from Santa Cruz Biotechnology, Inc. The polymerase chain reaction (PCR) technique was applied to isolate human GLRX1 cDNA. All remaining chemicals and reagents used in this experiment were of the highest available commercial grade.

Cell culture. HT-22 murine hippocampal neuronal cells were cultured in Dulbecco's modified Eagle's medium (Lonza Group, Ltd., Basel, Switzerland) supplemented with $10 \%$ fetal bovine serum (Lonza Group, Ltd.) and antibiotics $(100 \mu \mathrm{g} / \mathrm{ml}$ streptomycin, $100 \mathrm{U} / \mathrm{ml}$ penicillin) at $37^{\circ} \mathrm{C}$, under humidified conditions of $95 \%$ air and $5 \% \mathrm{CO}_{2}$.

Expression and purification of PEP-1-GLRX1 proteins. A cell permeable PEP-1 expression vector was prepared in the present laboratory as previously described $(19,20)$. The cDNA sequence for human GLRX1 was amplified by PCR using the following primer sequences: Forward, 5'-GGTCTC CTCGAGATGGCTCAAGAGTTTG-3' and reverse, 5'-GGA TCCTTACTGCAGAGCTCCAATCTG-3'. PCR products were excised, eluted (Expin Gel; GeneAll Biotechnology Co., Ltd., Seoul, Korea), and ligated into a TA cloning vector (pGEM ${ }^{\circledR}-\mathrm{T}$ easy vector; Promega Corporation, Madison, WI, USA) according to the manufacture's protocol. The purified TA vector containing human GLRX1 cDNA was ligated into the PEP-1 expression vector to produce a PEP-1-GLRX1 fusion protein. In a similar fashion, a control GLRX1 was constructed that expressed the GLRX1 protein without PEP-1. To produce the PEP-1-GLRX1 and control GLRX1 proteins, the plasmid was transformed into Escherichia coli BL21 cells. The transformed bacterial cells were grown in $100 \mathrm{ml}$ of lysogeny broth media at $37^{\circ} \mathrm{C}$ to a $\mathrm{D}_{600}$ value of $0.5-1.0$ and induced with $0.5 \mathrm{mM}$ isopropyl $\beta$-D-1-thiogalactopyranoside at $37^{\circ} \mathrm{C}$ for $6 \mathrm{~h}$. Harvested cells were lysed by sonication and purified using a $\mathrm{Ni}^{2+}$-nitrilotriacetic acid Sepharose affinity column (Qiagen, Inc.) and PD-10 column chromatography (GE Healthcare, Chicago, IL, USA). The purified protein concentrations were estimated using a Bradford assay (23).

Transduction of PEP-1-GLRX1 protein into HT-22 cells. To examine the transduction ability of PEP-1-GLRX1 protein, HT-22 cells were treated with various concentrations of PEP-1-GLRX1 protein (0.5-1.5 $\mu \mathrm{M})$ for $1 \mathrm{~h}$ or with $1.5 \mu \mathrm{M}$ for various time periods (10-60 min). Cells were then treated with trypsin-EDTA and washed with phosphate-buffered saline (PBS). The cells were harvested for the preparation of cell extracts to perform western blot analysis. Transduced PEP-1-GLRX1 protein was detected using an anti-histidine antibody (1:1,000; cat no. sc-804).

Western blot analysis. Following PEP-1-GLRX1 protein transduction, HT-22 cells were harvested and homogenized with NP-40 protein extraction solution (Elpis Biotech, Inc., Daejeon, South Korea) at $4^{\circ} \mathrm{C}$ for $20 \mathrm{~min}$. Protein concentration was determined by the Bradford assay. Equal amounts of protein (30 $\mu \mathrm{g} /$ lane) was resolved by $15 \%$ SDS-PAGE and the gels were subsequently transferred to a nitrocellulose membrane. The membrane was blocked with $5 \%$ non-fat milk for $1 \mathrm{~h}$ at $37^{\circ} \mathrm{C}$ in a Tris-buffered saline buffer with $0.1 \%$ Tween 20. The blocked membrane was incubated with histidine (1:1,000; cat no. sc-804), p-Akt (1:1,000; cat no. 9272S), Akt (1:1,000; cat no. 4058S), p-JNK (1:1,000; cat no. 9251S), JNK (1:1,000; cat no. 9258S), p-ERK (1:1,000; cat no. 4376S), ERK (1:1,000; cat no. 9102S), p-p38 (1:1,000; cat no. 4631S), p38 (1:1,000; cat no. 9212S), p-p53 (1:1,000; cat no. 9284S), p53 (1:1,000; cat no. 9282S), Bax (1:1,000; cat no. 2772S), Bcl-2 (1:1,000; cat no. ab59348), capase-9 (1:1,000; cat no. $9504 \mathrm{~S})$ and $\beta$-actin $(1: 1,000$; cat no. 4967S) primary antibodies overnight at $4^{\circ} \mathrm{C}$, followed by incubation with horseradish peroxidase-conjugated secondary antibodies $(1: 10,000$; cat no. $7074 \mathrm{~S})$ for $1 \mathrm{~h}$ at $37^{\circ} \mathrm{C}$. Bands were visualized with a Chemidoc imaging system (version 5.2; Bio-Rad Laboratories, Inc., Hercules, CA, USA) and an enhanced chemiluminescence kit according to the manufacturer's protocol (GE Healthcare) (24). Bands were quantified with ImageJ software (version 1.48; National Institutes of Health, Bethesda, MD, USA).

Fluorescence confocal microscopy analysis. The distribution of transduced proteins was assessed using fluorescence microscopy as previously described $(20,22)$. HT-22 cells were grown on coverslips and treated with PEP-1-GLRX1 protein $(1.5 \mu \mathrm{M})$ for $1 \mathrm{~h}$ and then washed twice with PBS, fixed with 
$4 \%$ paraformaldehyde at $37^{\circ} \mathrm{C}$ for $5 \mathrm{~min}$, permeabilized with $0.1 \%$ Triton $\mathrm{X}-100$ and blocked at $37^{\circ} \mathrm{C}$ for 40 min with $3 \%$ bovine serum albumin (Sigma-Aldrich; Merck KGaA) in PBS (PBS-BT) and washed with PBS-BT. The cells were incubated with an anti-histidine antibody (1:2,000; Santa Cruz Biotechnology, Inc.) for $1 \mathrm{~h}$ at $37^{\circ} \mathrm{C}$, followed by incubation with Alexa Fluor 488-conjugated secondary antibody (1:15,000; Invitrogen; Thermo Fisher Scientific, Inc., Waltham, MA, USA) in the dark for $1 \mathrm{~h}$ at $37^{\circ} \mathrm{C}$. Nuclei were then stained for $3 \mathrm{~min}$ with $1 \mu \mathrm{g} / \mathrm{ml}$ DAPI diluted 1:3,000 (Roche Diagnostics $\mathrm{GmbH}$, Mannheim, Germany) At each step, the cells were washed with PBS-BT three times. Coverslips were mounted onto glass slides with Dako fluorescent mounting solution (Agilent Technologies, Inc., Santa Clara, CA, USA) The cells were analyzed by confocal microscopy using a model FV-300 microscope (magnification, x630; Olympus Corporation, Tokyo, Japan).

3-(4,5-dimethylthiazol-2-yl)-2,5-diphenyltetrazolium bromide (MTT) assay. Briefly, HT-22 cells were pretreated with PEP-1-GLRX1 protein $(0.5-1.5 \mu \mathrm{M})$ for $1 \mathrm{~h}$ and then treated with hydrogen peroxide $\left(\mathrm{H}_{2} \mathrm{O}_{2}, 1 \mathrm{mM}\right)$ for $3 \mathrm{~h}$. A cell viability assay was performed using MTT as previously described $(20,22)$. The absorbance was read at a wavelength of $570 \mathrm{~nm}$ using an ELISA microplate reader (Labsystems Multiskan MCC/340) and cell viability was defined as the \% of untreated control cells.

Measurement of oxidative stress-induced intracellular ROS levels. DCF-DA dye was used to measure intracellular ROS levels, which was converted into fluorescent 2'7'-dichlorofluorescein (DCF) by ROS (22). HT-22 cells were incubated in the absence or presence of PEP-1-GLRX1 $(1.5 \mu \mathrm{M})$ for $1 \mathrm{~h}$ prior to treatment with $\mathrm{H}_{2} \mathrm{O}_{2}(1 \mathrm{mM})$ for $10 \mathrm{~min}$. Those cells were washed twice with PBS and then incubated at $37^{\circ} \mathrm{C}$ for $30 \mathrm{~min}$ using DCF-DA $(10 \mu \mathrm{M})$. The image was produced at $485 \mathrm{~nm}$ excitation and $538 \mathrm{~nm}$ emission using a Fluoroskan ELISA plate reader (Labsystems Oy, Helsinki, Finland).

Terminal deoxynucleotidyl transferase dUTP nick end labeling (TUNEL) assay. To investigate DNA fragmentation, TUNEL staining was performed using a Cell Death Detection Kit (Roche Applied Science, Penzberg, Germany) according to the manufacturer's protocol (22). Briefly, HT-22 cells were incubated in the absence or presence of PEP-1-GLRX1 $(1.5 \mu \mathrm{M})$ for $1 \mathrm{~h}$, and then treated with $\mathrm{H}_{2} \mathrm{O}_{2}(1 \mathrm{mM})$ for $5 \mathrm{~h}$. Next, nuclei were stained at $37^{\circ} \mathrm{C}$ for 3 min with $1 \mu \mathrm{g} / \mathrm{ml} \mathrm{DAPI}$ and washed with PBS. Coverslips were mounted onto glass slides using Dako fluorescent mounting solution (CA, USA). Images were taken using a fluorescence microscope (Nikon Eclipse 80i; Nikon Corporation, Tokyo, Japan). TUNEL-positive cells were counted by phase-contrast microscopy in at least 5 random fields at x200 magnification.

Measurement of apoptotic protein expression. HT-22 cells were incubated in the absence or presence of PEP-1-GLRX1 (1-1.5 $\mu \mathrm{M}$ ) for $1 \mathrm{~h}$, and then treated with $\mathrm{H}_{2} \mathrm{O}_{2}$ for various time periods. The expression levels of Bcl-2 (1 h), Bax (2 h), and pro-caspase-9 (4 h) in whole cell lysates were analyzed by western blotting using respective antibodies as described above. The bands were quantified by Image J software (version 1.4.8; National Institutes of Health).

Experimental animals and induction of cerebral forebrain ischemia. Male Mongolian gerbils (70-80 g; 6 months old; $\mathrm{n}=40$ ) were obtained from the Experimental Animal Center of Soonchunhyang University (Cheonan, Korea). The animals were housed at an adequate temperature $\left(23^{\circ} \mathrm{C}\right)$ and humidity $(60 \%)$ with a $12 \mathrm{~h}$ light/12 h dark cycle, and free access to food and water. All experimental procedures involving animals and their care conformed to the Guide for the Care and Use of Laboratory Animals of the National Veterinary Research \& Quarantine Service of Korea and were approved by the Institutional Animal Care and Use Committee of Soonchunhyang University (Cheonan-Si, Korea; SCH16-0024).

Cerebral forebrain ischemia damage was induced as previously described $(25,26)$. Briefly, the animals were anesthetized with a mixture of $2.5 \%$ isoflurane (Baxtor Healthcare, Deerfield, IL, USA) in $33 \%$ oxygen and $67 \%$ nitrous oxide. Bilateral common carotid arteries were isolated and occluded using nontraumatic aneurysm clips. The complete interruption of blood flow was verified by observing the central retinal artery using an ophthalmoscope. Following 5 min of occlusion, the aneurysm clips were removed from the common carotid arteries. The body temperature under free-regulating or normothermic $\left(37 \pm 0.5^{\circ} \mathrm{C}\right)$ conditions was monitored with a rectal temperature probe (TR-100; Fine Science Tools, Foster City, CA, USA) and maintained using a thermometric blanket prior to, during, and following surgery until the animals completely recovered from anesthesia. Thereafter, the animals were kept on the thermal incubator (Mirae Medical Industry, Seoul, South Korea) to maintain body temperature until the animals were euthanized.

Treatment of ischemic animals with PEP-1-GLRX1 and immunohistochemistry. To explore the protective effects of PEP-1-GLRX1 protein against ischemic damage, the animals were divided into 4 groups ( $n=10$ per group); control sham group (normal control), model group (ischemia control), control GLRX1-treated group, and PEP-1-GLRX1-treated group (each $2 \mathrm{mg} / \mathrm{kg}$ ). The control GLRX1 and PEP-1-GLRX1 proteins were administered intraperitoneally $30 \mathrm{~min}$ following ischemia-reperfusion.

Immunohistochemistry was performed as described in previous studies $(20,22)$. The brain tissue samples were obtained 7 days following ischemia-reperfusion. To examine the protective effects of PEP-1-GLRX1 protein against ischemic damage, the sections were stained overnight at $4{ }^{\circ} \mathrm{C}$ with histidine (1:500; cat no. sc-804), neuronal nuclei (NeuN; 1:100; cat no. MAB377; EMD Millipore, Billerica, MA, USA), $0.5 \%$ cresyl violet acetate (CV; cat no. 10510-54-0; Sigma-Aldrich; Merck KGaA), Fluoro-Jade B (FJB; 1:500; cat no. AG310-30MG; EMD Millipore), glial fibrillary acidic protein (GFAP; 1:500; cat no. AB5804; EMD Millipore) and ionized calcium-binding adapter molecule 1 (Iba-1; 1:500; cat no. 019-19741; Wako Pure Chemical Industries, Ltd., Osaka, Japan). Subsequently, sections were incubated with biotinylated goat anti-mouse IgG antibody (1:200; cat no. BA-9200; Vector Laboratories, Inc. Burlingame, CA, USA) or biotinylated goat anti-rabbit IgG antibody (1:200: cat no. BA-1,000; 
Vector Laboratories, Inc.) for $1 \mathrm{~h}$ at $25^{\circ} \mathrm{C}$. A cell count was conducted in the hippocampal area to quantify immunostaining as described in a previous study $(20,22)$.

Statistical analysis. Data are expressed as the mean \pm standard error of the mean of three experiments. Differences between groups were analyzed by one-way analysis of variance followed by a Bonferroni's post-hoc test using GraphPad Prism software (version 5.01; GraphPad Software Inc., San Diego, CA, USA). $\mathrm{P}<0.05$ was considered to indicate a statistically significant difference.

\section{Results}

Construction and purification of PEP-1-GLRX1 protein. The present study constructed a cell permeable PEP-1-GLRX1 protein expression vector. As presented in Fig. 1A, the vector contained a cDNA sequence with an amino-terminal tag containing human GLRX1, PEP-1 peptide and 6 histidine residues. A control GLRX1 expression vector without the PEP-1 peptide was also constructed. PEP-1-GLRX1 and control GLRX1 proteins were overexpressed in bacterial cells and purified by using $\mathrm{Ni}^{2+}$-NTA and PD-10 column chromatography. The purified PEP-1-GLRX1 and control GLRX1 proteins were verified using SDS-PAGE and western blot analysis (Fig. 1B and C).

Transduction of PEP-1-GLRX1 protein into HT-22 cells. To examine of transduction ability of PEP-1-GLRX1 protein, HT-22 cells were treated with PEP-1-GLRX1 proteins at various concentrations $(0.5-1.5 \mu \mathrm{M})$ for $1 \mathrm{~h}$. Cells were also treated with the same concentration of PEP-1-GLRX1 protein $(1.5 \mu \mathrm{M})$ for various times $(10-60 \mathrm{~min})$. The transduction of PEP-1-GLRX1 protein was verified by western blotting. As presented in Fig. 2A and B, PEP-1-GLRX1 protein concentration- and time-dependently transduced into HT-22 cells. However, control GLRX1 protein did not transduce into the cells. Furthermore, transduced PEP-1-GLRX1 protein was examined using DAPI and histidine immunostaining. Through immunostaining signals, it was verified that PEP-GLRX1 protein efficiently transduced into HT-22 cells (Fig. 2C). Since the stability of protein is a significant factor in the development of therapeutic agents, the stability of transduced PEP-1-GLRX1 protein was measured. As presented in Fig. 2D, the concentration of transduced PEP-1-GLRX1 protein in the cells decreased following $24 \mathrm{~h}$, however remained present for up to a maximum of $60 \mathrm{~h}$.

Effects of PEP-1-GLRX1 on cell survival from oxidative stress. In order to examine whether transduced PEP-1-GLRX1 protein has protective effects against $\mathrm{H}_{2} \mathrm{O}_{2}$-induced HT-22 cell death, the present study measured cell viability using an MTT assay. As presented in Fig. 3A, when cells were treated with $\mathrm{H}_{2} \mathrm{O}_{2}$, cell survival was $\sim 50 \%$. PEP-1-GLRX1 protein markedly increased cell viability to up to $73 \%$ dose-dependently. However, control GLRX1 protein did not demonstrate the protective effects in $\mathrm{H}_{2} \mathrm{O}_{2}$ treated cells. There was no protective effect on cell viability when the PEP-1 peptide alone was used for treatment under the same conditions (data not shown).
A

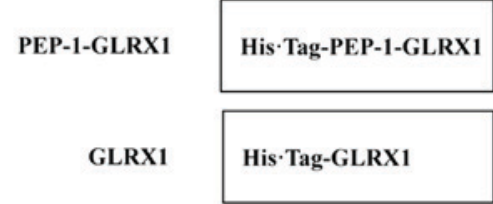

B

C

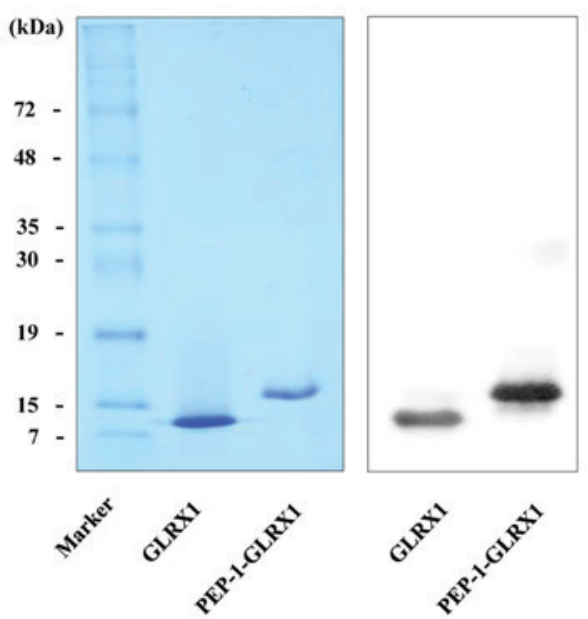

Figure 1. Construction and purification of PEP-1-GLRX1 proteins (A) Constructed map of PEP-1-GLRX1 based on the pET15-b vector and diagrams of the expressed PEP-1-GLRX1 proteins. Purified recombinant PEP-1-GLRX1 and control GLRX1 proteins were identified by (B) $15 \%$ SDS-PAGE and were verified by (C) western blot analysis using an anti-histidine antibody. His, histidine; GLRX1, glutaredoxin 1.

In addition, intracellular ROS production levels were investigated. In $\mathrm{H}_{2} \mathrm{O}_{2}$ exposed cells, intracellular ROS levels were markedly increased, whereas ROS levels were significantly reduced by PEP-1-GLRX1 protein. However, control GLRX1 protein did not affect ROS levels (Fig. 3B). It was also investigated whether transduced PEP-1-GLRX1 protein inhibits DNA damage resulting from $\mathrm{H}_{2} \mathrm{O}_{2}$ using TUNEL and 8-OHdG staining (Fig. 3C and D). In the $\mathrm{H}_{2} \mathrm{O}_{2}$ exposed cells, TUNEL or 8-OHdG-positive cells were markedly increased compared with the non-treated control cells. However, TUNEL and 8-OHdG-positive cells were significantly decreased by PEP-1-GLRX1 protein. Conversely, there was no protective effect against $\mathrm{H}_{2} \mathrm{O}_{2}$-induced DNA damage in the control GLRX1 protein treated cells. These results indicated that transduced PEP-1-GLRX1 protein protected against $\mathrm{H}_{2} \mathrm{O}_{2}$-induced HT-22 cell death via suppression of intracellular ROS production and DNA damage.

PEP-1-GLRX1 prevents $\mathrm{H}_{2} \mathrm{O}_{2}$-induced $\mathrm{RAC}$-a serine/threonine-protein kinase (Akt) and mitogen activated protein kinase (MAPK) activation. Excessive intracellular ROS production leads to the activation of MAPK pathways in various cell types. $\mathrm{H}_{2} \mathrm{O}_{2}$ is known as an oxidizing agent which induces the activation of MAPK pathways (5). Therefore, the present study investigated whether the role of PEP-1-GLRX1 protein is in response to the activation of Akt and MAPK [JUN N-terminal kinase (JNK), extracellular signal-regulated kinase (ERK)1/2, and p38) in $\mathrm{H}_{2} \mathrm{O}_{2}$ exposed HT-22 cells (Fig. 4). When cells were 
A
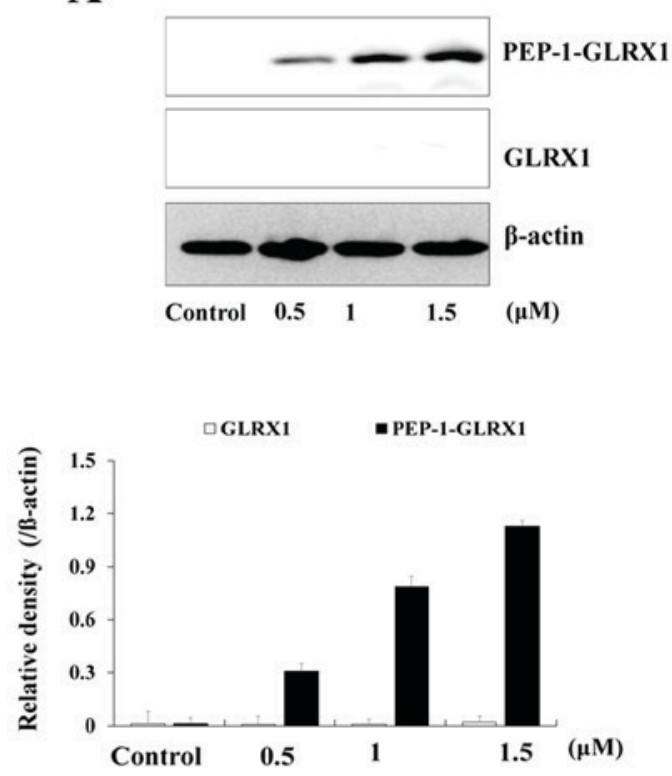

C

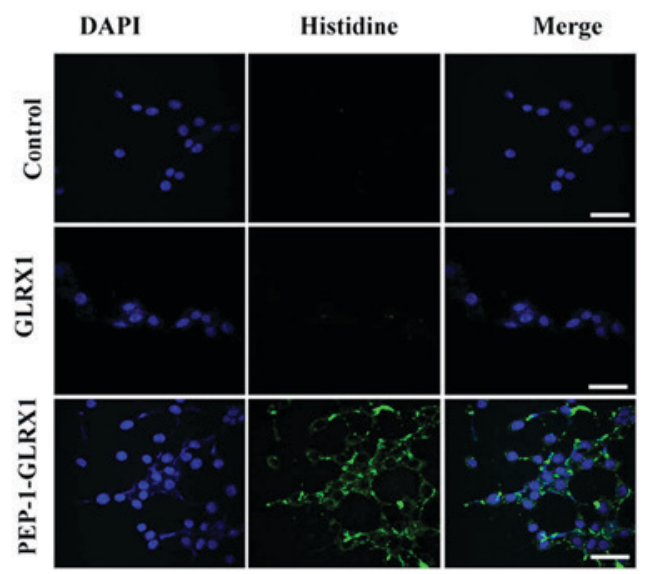

B
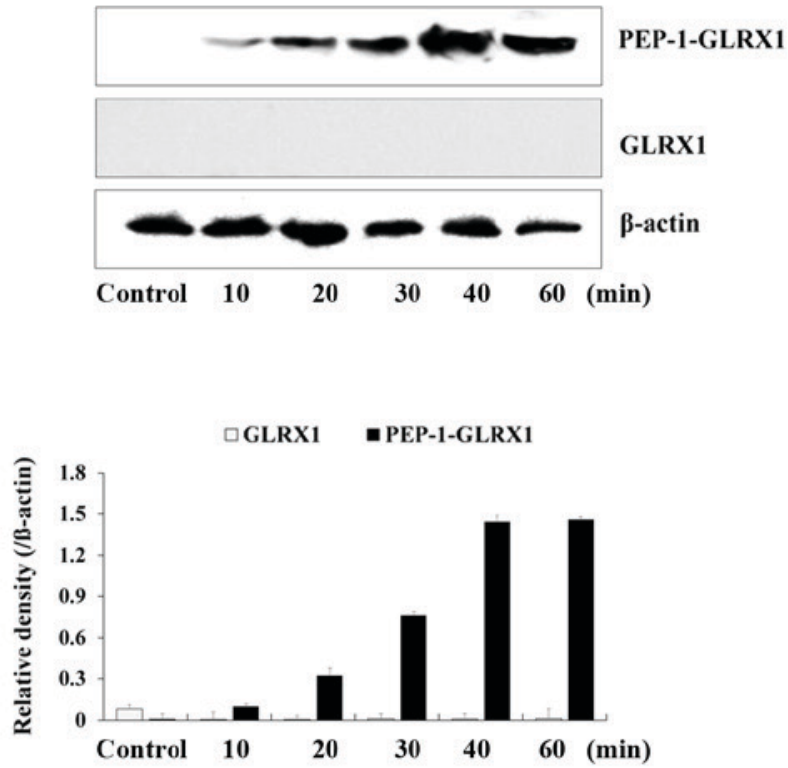

D
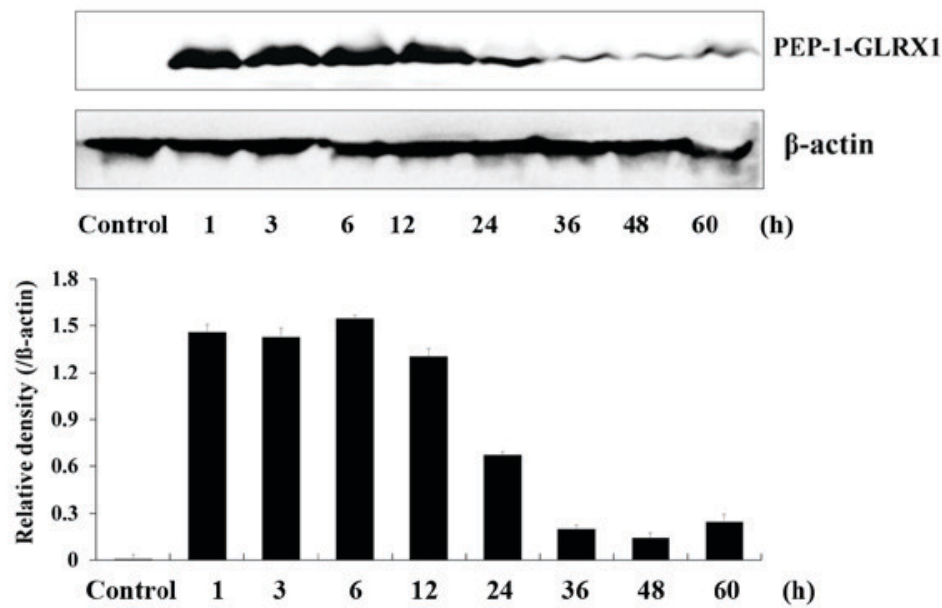

Figure 2. Transduction of PEP-1-GLRX1 proteins into HT-22 cells. (A) PEP-1-GLRX1 and control GLRX1 proteins $(0.5-1.5 \mu \mathrm{M})$ were added to the HT-22 culture medium for $1 \mathrm{~h}$. (B) PEP-1-GLRX1 and GLRX1 proteins $(1.5 \mu \mathrm{M})$ were added to the HT-22 culture medium for 10-60 min and analyzed by western blotting using an anti-histidine antibody, and the band intensity was measured by densitometry. (C) Cellular localization of transduced PEP-1-GLRX1 proteins was verified by fluorescence microscopy. Scale bar=20 $\mu \mathrm{m}$. (D) Stability of the transduced PEP-1-GLRX1 proteins $(1.5 \mu \mathrm{M})$ in the HT-22 cells was analyzed by western blotting and the band intensity was measured by densitometry. $\beta$-actin was used as a loading control. GLRX1, glutaredoxin 1 .

exposed $\mathrm{H}_{2} \mathrm{O}_{2}$, the activation levels of Akt and MAPK [phosphorylated (p)-Akt and p-MAPK] were markedly increased, however PEP-1-GLRX1 protein significantly inhibited p-Akt and p-MAPK levels in a concentration-dependent manner. However, levels of p-Akt and p-MAPK were not significantly altered in control GLRX1 protein and non-treated control cells. The results provided evidence that transduced PEP-1-GLRX1 inhibited the activation of Akt and MAPK in $\mathrm{H}_{2} \mathrm{O}_{2}$ exposed HT-22 cells.

PEP-1-GLRX1 protects $\mathrm{HT}-22$ cells against $\mathrm{H}_{2} \mathrm{O}_{2}$-mediated apoptosis. It is well known that oxidative stress promotes activation of apoptotic signaling pathways $(27,28)$. Therefore, the present study determined the ability of PEP-1-GLRX1 protein to inhibit $\mathrm{H}_{2} \mathrm{O}_{2}$-induced apoptotic pathways. Firstly, the expression levels of p-p53 were verified as oxidative stress increases expression levels of p-p53. As presented in Fig. 5A, the levels of p-p53 were significantly increased in the $\mathrm{H}_{2} \mathrm{O}_{2}$ exposed cells, whereas the levels were markedly inhibited in cells treated with PEP-1-GLRX1 protein in a concentration-dependent manner. However, control GLRX1 protein did not alter the expression level of p-p53 in $\mathrm{H}_{2} \mathrm{O}_{2}$ exposed cells

The mechanism of the anti- or pro-apoptotic effects of PEP-1-GLRX1 protein were additionally investigated. As presented in Fig. 5B, increased Bax expression levels resulting from $\mathrm{H}_{2} \mathrm{O}_{2}$ were significantly reduced in the cells treated with PEP-1-GLRX1 protein. Conversely, Bax expression levels were not reduced in the control GLRX1 protein treated cells. 
A

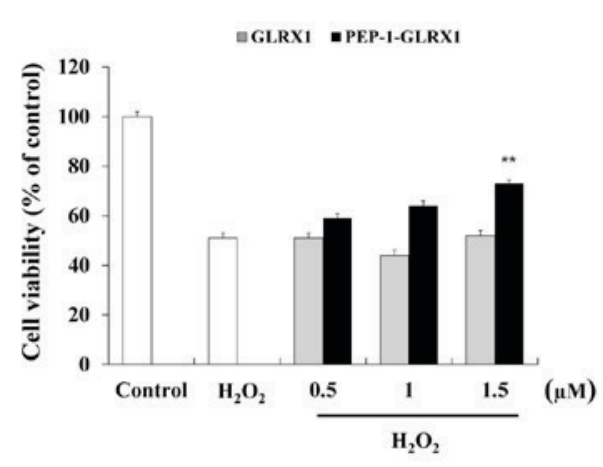

B
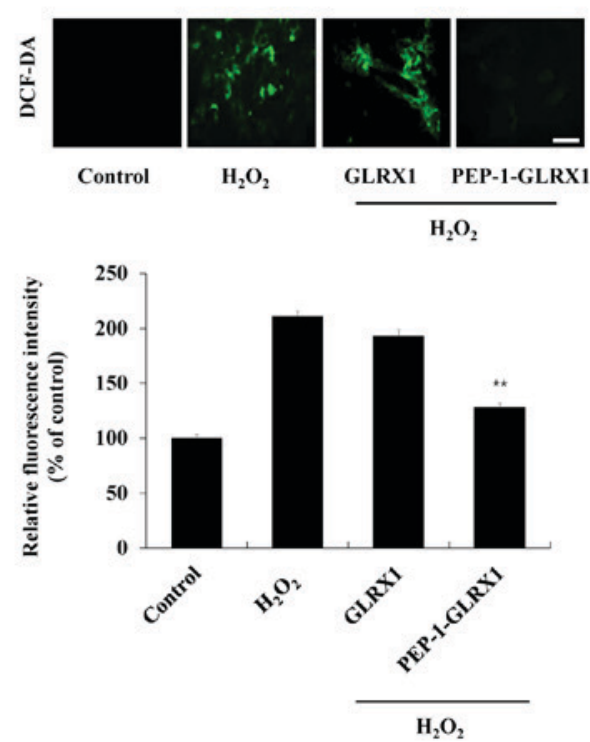

C

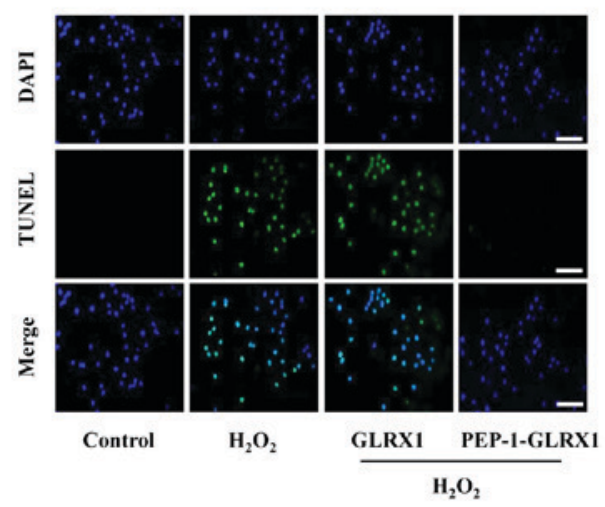

D

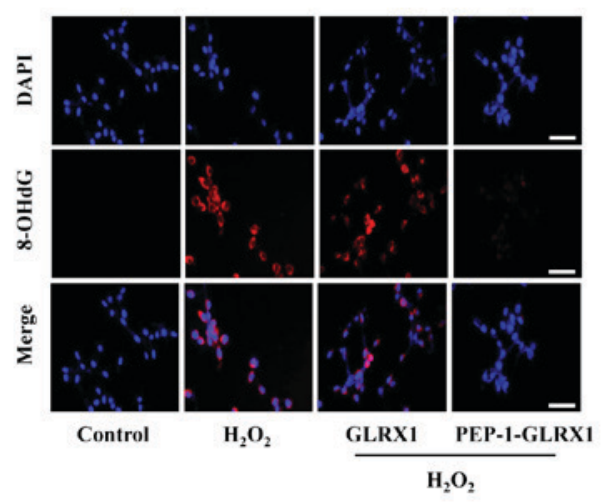

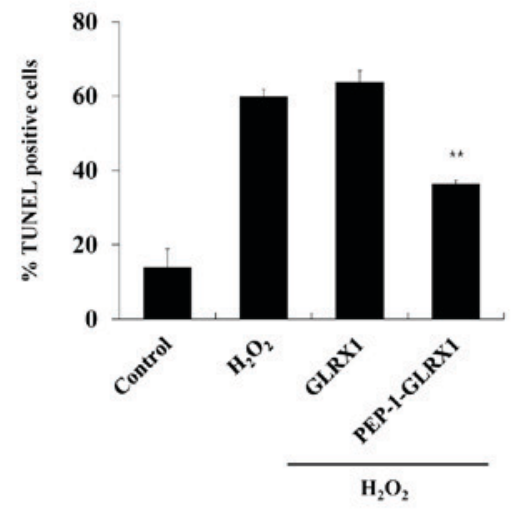

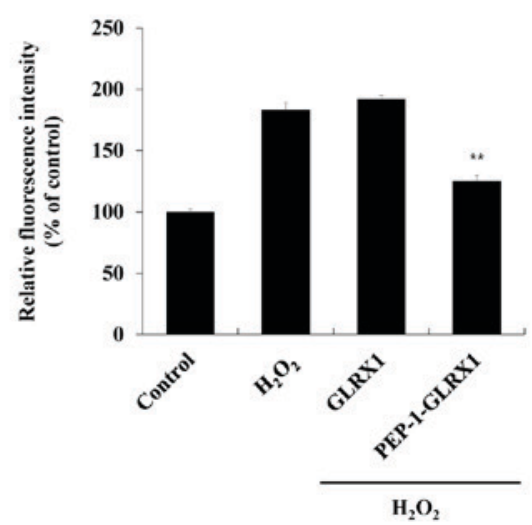

Figure 3. Effect of PEP-1-GLRX1 protein against oxidative stress-induced cell death. HT-22 cells were pretreated with PEP-1-GLRX1 and control GLRX1 $(1.5 \mu \mathrm{M})$ proteins for $1 \mathrm{~h}$ prior to addition of hydrogen peroxide $(1 \mathrm{mM})$ to the culture medium. (A) Cell viabilities were assessed by the MTT-based colorimetric assay. (B) Intracellular reactive oxygen species levels were measured by DCF-DA staining and the fluorescence intensity was measured using an ELISA plate reader. DNA damage was detected by (C) TUNEL and (D) 8 -OHdG staining. Scale bar, $50 \mu \mathrm{m}$. Images were taken using a fluorescence microscope and the fluorescence intensity was measured using an ELISA plate reader. ${ }^{* *} \mathrm{P}<0.01$ vs. $\mathrm{H}_{2} \mathrm{O}_{2}$-treated cells. GLRX1, glutaredoxin 1; DCF-DA, 2',7'-Dichlorofluorescein diacetate; 8-OHdG, 8-hydroxy-2-deoxyguanosine; TUNEL, terminal deoxynucleotidyl transferase dUTP nick end labeling; $\mathrm{H}_{2} \mathrm{O}_{2}$, hydrogen peroxide.

As presented in Fig. 6, Bcl-2 and pro-caspase-9 expression levels were significantly decreased in the $\mathrm{H}_{2} \mathrm{O}_{2}$ exposed cells compared with the non-treated control cells, whereas Bcl-2 and pro-caspase-9 expression levels were markedly recovered in a concentration-dependent manner in cells treated with PEP-1-GLRX1 protein. However, the alterations of $\mathrm{Bcl}-2$ and pro-caspase- 9 expression levels in control GLRX1 protein treated cells were 

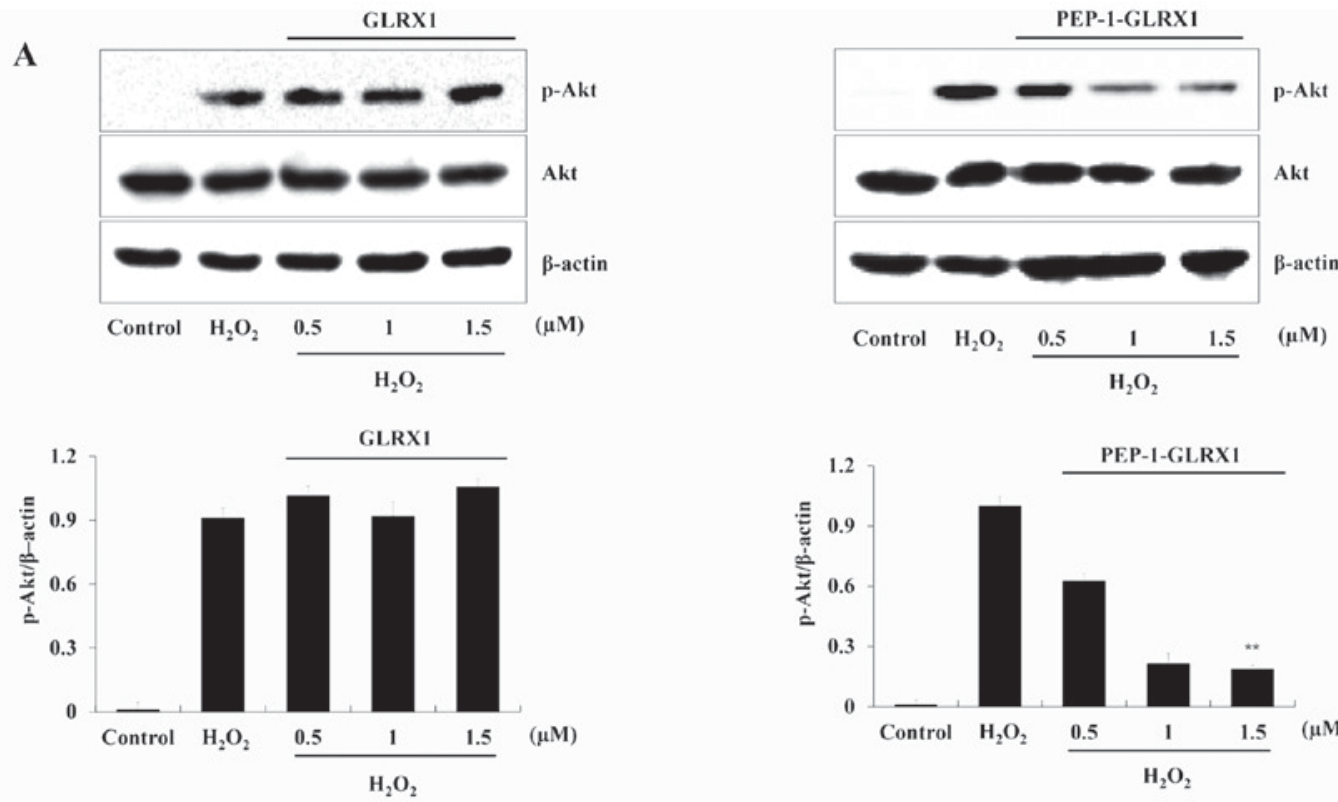

B
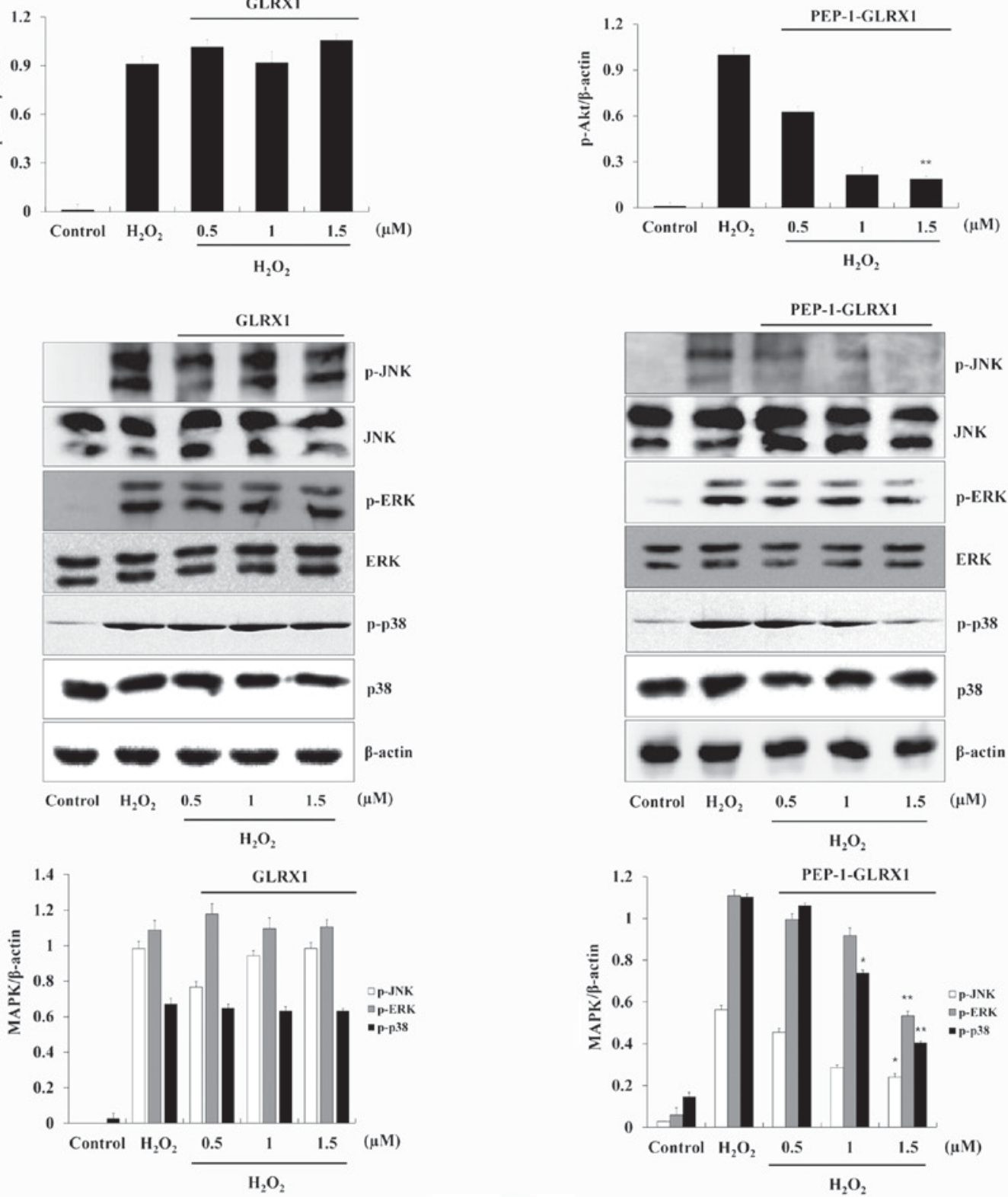

Figure 4. Effect of transduced PEP-1-GLRX1 protein against $\mathrm{H}_{2} \mathrm{O}_{2}$-induced Akt and MAPK activation. HT-22 cells were treated with PEP-1-GLRX1 and control GLRX1 (0.5-1.5 $\mu \mathrm{M})$ for $1 \mathrm{~h}$, and then exposed to $\mathrm{H}_{2} \mathrm{O}_{2}(1 \mathrm{mM})$. Then, the expression levels of (A) Akt and (B) MAPKs were measured by western blotting and the band intensity was measured by densitometry. ${ }^{*} \mathrm{P}<0.05 ;{ }^{* *} \mathrm{P}<0.01 \mathrm{vs} . \mathrm{H}_{2} \mathrm{O}_{2}$-treated cells. Akt, RAC-a serine/threonine-protein kinase; MAPK, mitogen activated protein kinase; GLRX1, glutaredoxin 1; $\mathrm{H}_{2} \mathrm{O}_{2}$, hydrogen peroxide; p, phosphorylated; JNK, JUN N-terminal kinase; ERK, extracellular signal-regulated kinase.

similar to the alterations induced by $\mathrm{H}_{2} \mathrm{O}_{2}$, indicating that PEP-1-GLRX1 efficiently inhibited $\mathrm{H}_{2} \mathrm{O}_{2}$-induced HT-22 cell death by preventing the activation of apoptotic signaling pathways.
PEP-1-GLRX1 protects against neuronal cell death in ischemic animal model. PTD fusion proteins are well known for their ability to transduce into the animal brain, crossing the blood-brain barrier (BBB) and improving neuronal 
A
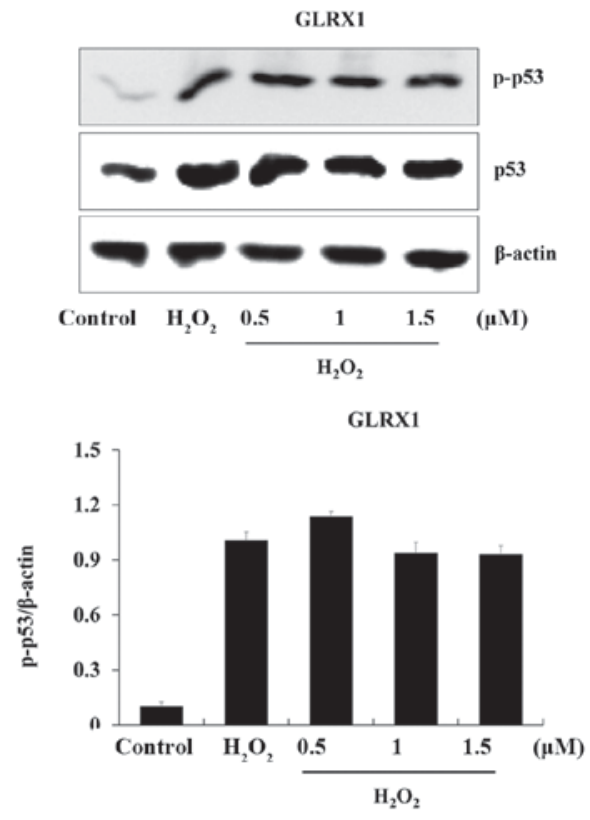

B
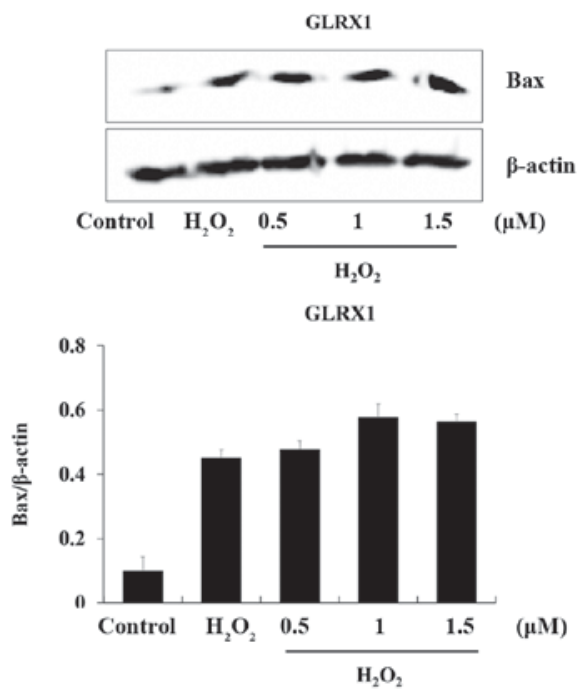
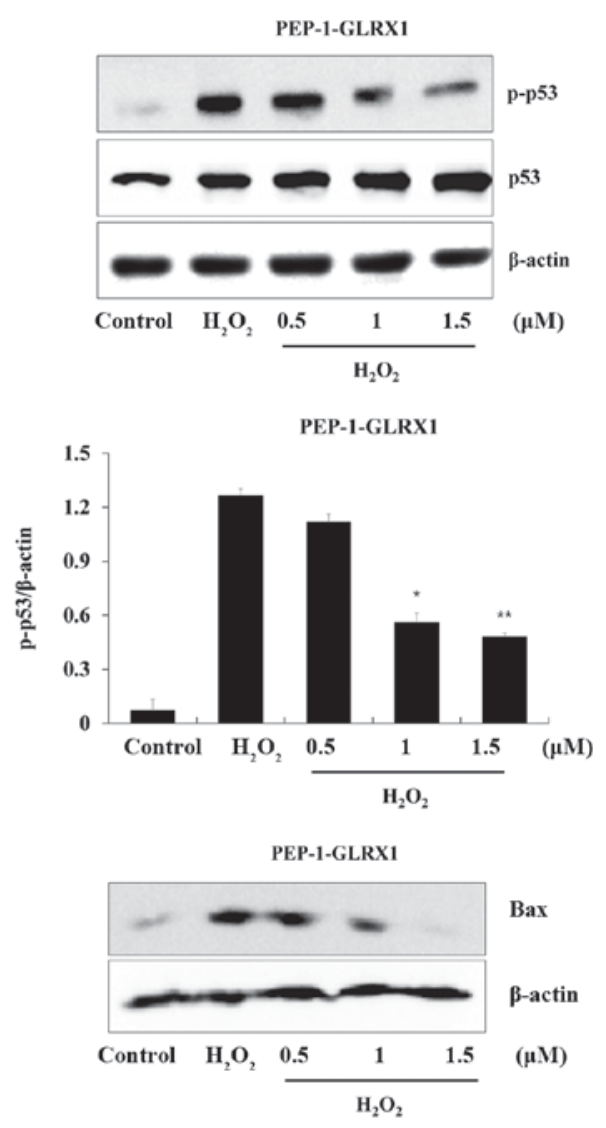

PEP-1-GLRX1

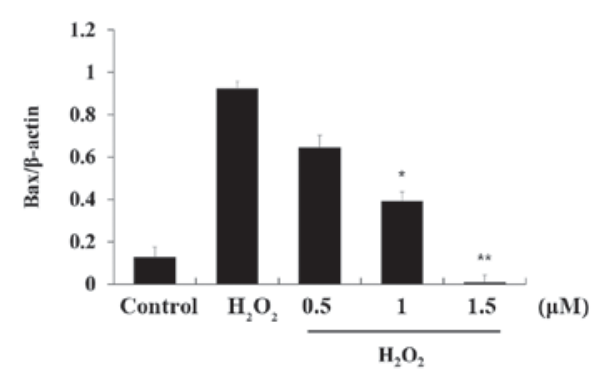

Figure 5. Effect of PEP-1-GLRX1 protein against $\mathrm{H}_{2} \mathrm{O}_{2}$-induced p53 and Bax expression. HT-22 cells were exposed to $\mathrm{H}_{2} \mathrm{O}_{2}(1 \mathrm{mM})$ with or without pretreatment with PEP-1-GLRX1 protein for $1 \mathrm{~h}$. (A) p53 and (B) Bax expression levels were analyzed by western blotting and the band intensity was measured by densitometry. " $\mathrm{P}<0.05 ;{ }^{* *} \mathrm{P}<0.01$ vs. $\mathrm{H}_{2} \mathrm{O}_{2}$-treated cells. GLRX1, glutaredoxin $1 ; \mathrm{H}_{2} \mathrm{O}_{2}$, hydrogen peroxide; p, phosphorylated; Bcl-2, B cell lymphoma-2; Bax, Bcl-2 associated $\mathrm{X}$, apoptosis regulator.

cell survival (13). Therefore, the present study determined whether PEP-1-GLRX1 protein transduced into the animal brain and the neuroprotective effects of PEP-1-GLRX1 in an animal model of ischemic injury. PEP-1-GLRX1 protein $(2 \mathrm{mg} / \mathrm{kg}$ ) was intraperitoneally injected into gerbils $30 \mathrm{~min}$ following ischemia-reperfusion. A total of 7 days following ischemic brain injury, the transduction of PEP-1-GLRX1 protein into the Cornu Ammonis (CA)1 region was verified, and cell viability determined. As presented in Fig. 7, in the sham control-, vehicle-, and control GLRX1 protein-treated groups, there were no differences in the Histidine antibody staining. However, in the PEP-1-GLRX1 protein treated groups, fluorescent stained signals were markedly increased compared with the sham control groups. In addition, through NeuN-immunostaining it was revealed that PEP-1-GLRX1 protein increased neuronal cell survival in the CA1 region.
The protective effect of PEP-1-GLRX1 proteins against ischemic brain injury were investigated by $\mathrm{CV}$ and $\mathrm{FJB}$ staining, which are known to be sensitive markers for the detection of neuronal injury (Fig. 8). In the PEP-1-GLRX1 protein treated groups, CV-positive neurons were significantly increased compared with the vehicle-treated groups. However, the number of $\mathrm{CV}$-positive neurons were similar in the control GLRX1 protein-treated and vehicle-treated groups. In addition, FJB positive neuronal cells were not evident in the sham control group, whereas FJB positive neuronal cells were observed in the vehicle- and control GLRX1 protein treated group of the CA1 regions. FJB positive neuronal cells were significantly reduced in the PEP-1-GLRX1 protein-treated group compared with the vehicle-treated group.

Since the activation of astrocytes and microglia are known risk factors in ischemic injury (29), glial fibrillary acidic protein (GFAP) and Iba-1 immunostaining were performed to examine 
A
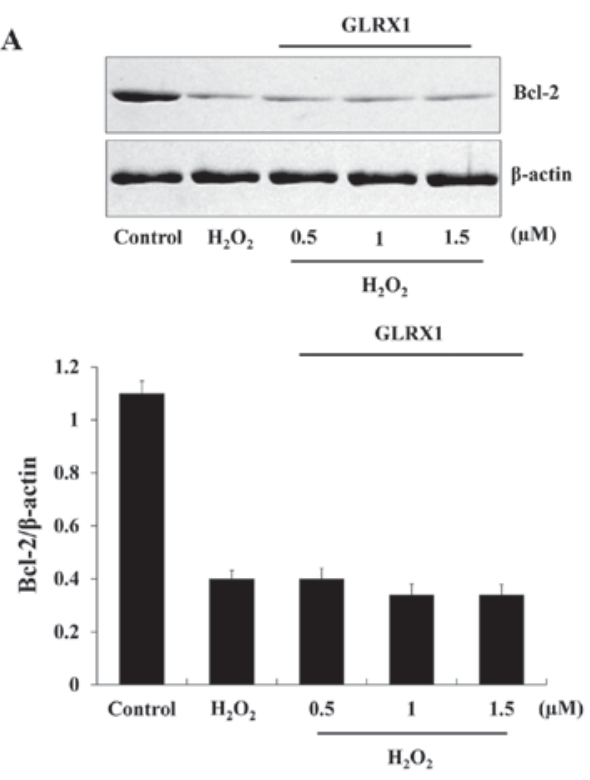

B

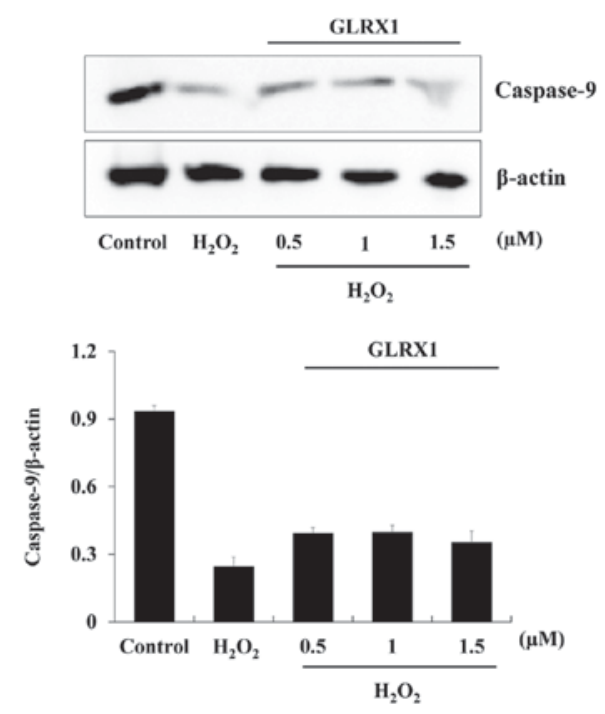

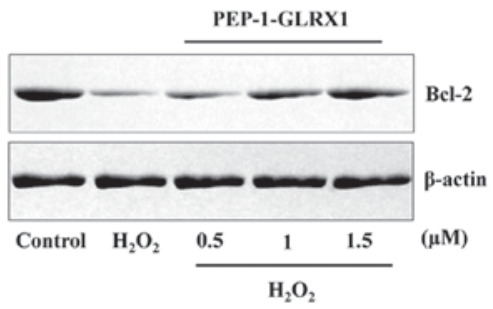
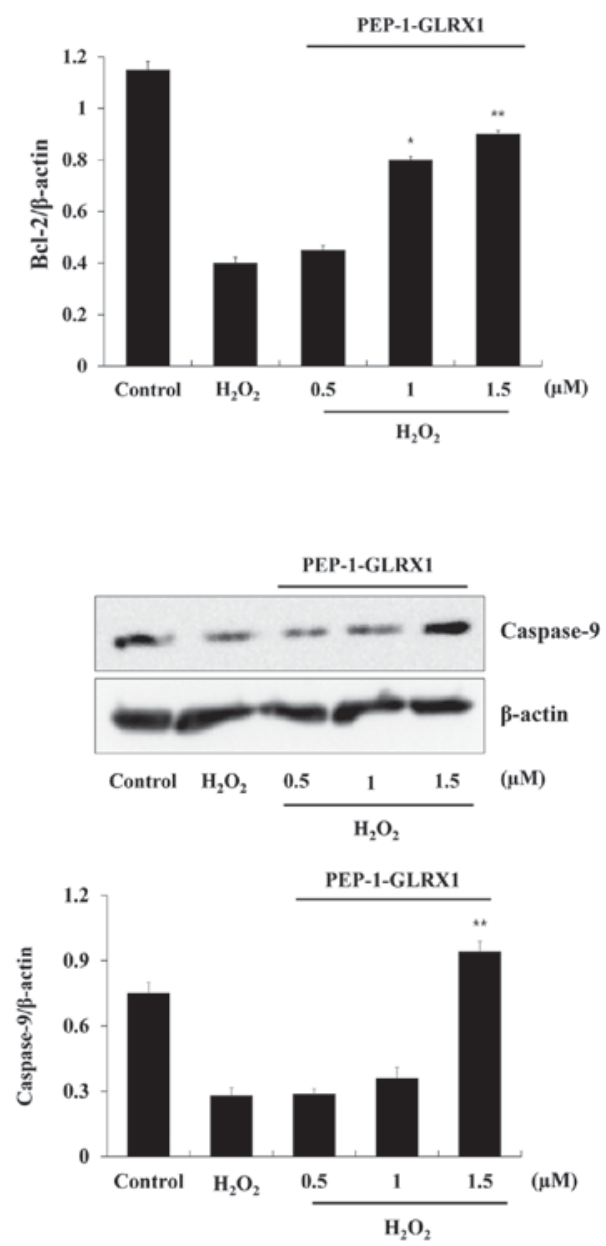

Figure 6. Effect of transduced PEP-1-GLRX1 on the expression levels of Bcl-2 and pro-caspase-9 in HT-22 cells. The cells were treated with PEP-1-GLRX1 $(0.5-1.5 \mu \mathrm{M})$ for $1 \mathrm{~h}$, and then exposed to $\mathrm{H}_{2} \mathrm{O}_{2}(1 \mathrm{mM})$. (A) Expression levels of Bcl-2 and (B) pro-caspase-9 were measured by western blotting and the band intensity was measured by densitometry. ${ }^{*} \mathrm{P}<0.05 ;{ }^{* *} \mathrm{P}<0.01$ vs. $\mathrm{H}_{2} \mathrm{O}_{2}$-treated cells. GLRX1, glutaredoxin $1 ; \mathrm{H}_{2} \mathrm{O}_{2}$, hydrogen peroxide; Bcl-2, B cell lymphoma-2.

whether transduced PEP-1-GLRX1 protein inhibited the activation of astrocytes and microglia in the CA1 region (Fig. 8). In the vehicle-treated group, GFAP-immunoreactive astrocytes were significantly increased in the CA1 regions, similar to those of control GLRX1 protein-treated groups. However, GFAP-immunoreactive astrocytes were markedly reduced in the PEP-1-GLRX1 protein-treated group compared with the vehicle-treated group. In addition, Iba-1-immunoreactive microglia in the CA1 region were significantly increased and aggregated in the vehicle-treated group, similar to that of the control GLRX1 protein-treated group. In the PEP-1-GLRX1 protein-treated groups, Iba-1-immunoreactive microglia aggregation recovered to a similar level as the sham control group. Overall, the results provided evidence that transduced PEP-1-GLRX1 protein markedly protected against neuronal cell death and may act as a therapeutic agent against ischemic brain injury.

\section{Discussion}

Human GLRX1, a member of GLRX family, is a GSH-dependent thiol oxidoreductase and is a small multifunctional protein. The two predominant forms (GLRX1 and GLRX2) exist in mammalian systems and GLRX1 is primarily located in the cytoplasm and GLRX2 in the mitochondria and nucleus (30). A previous study demonstrated that overexpressed GLRX1 protects Akt from $\mathrm{H}_{2} \mathrm{O}_{2}$-induced oxidation and protects cells from apoptosis via regulation of the redox state of Akt in cardiac H9c2 cells (31). Conversely, other studies have demonstrated that GLRX1 has an important role in defense against oxidative stress and cellular redox homeostasis (32). However, the roles of the GLRX1 protein against oxidative stress-induced neuronal cell damage are not yet clear.

Although beneficial proteins were considered as potential therapeutic agents, the application of these proteins has been 

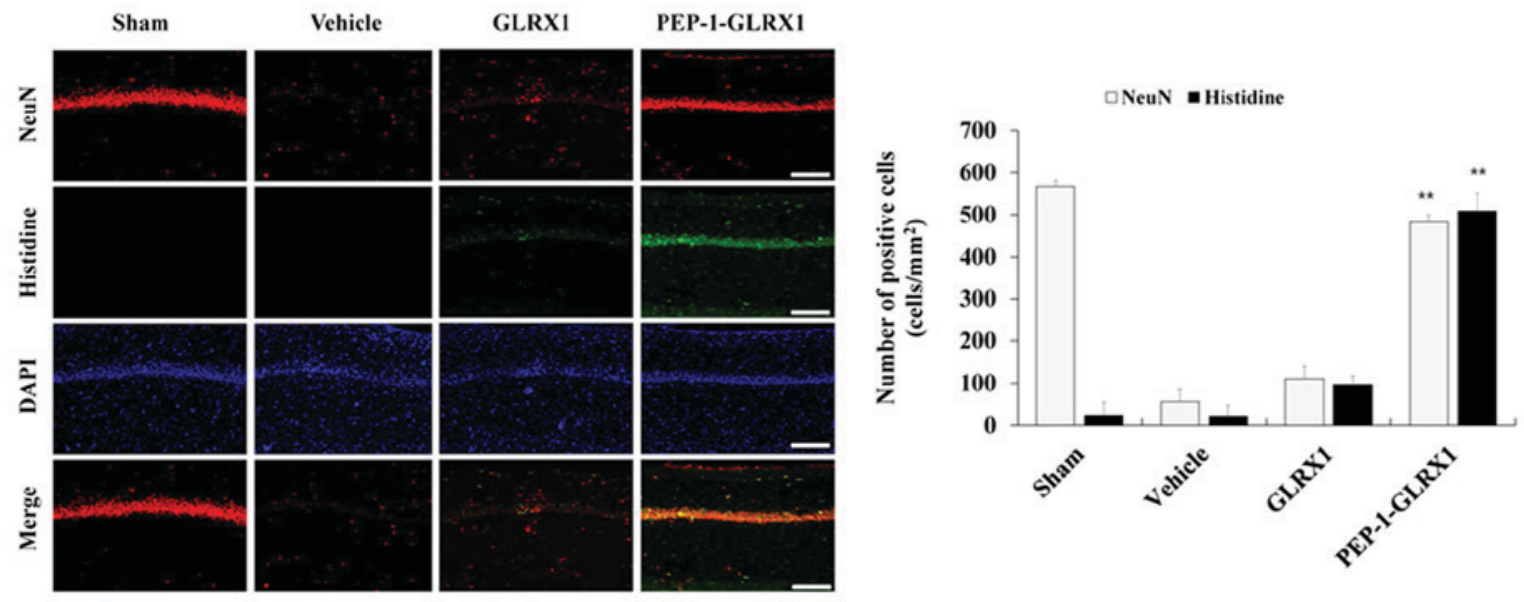

Figure 7. PEP-1-GLRX1 protein transduction into the animal brain. Gerbils were treated with single injections of PEP-1-GLRX1 (2 mg/kg). A total of 7 days following ischemic insults, transduced PEP-1-GLRX1 protein and its effects were verified using an anti-histidine, NeuN, and DAPI immunostaining. Scale bar $=50 \mu \mathrm{m} .{ }^{* *} \mathrm{P}<0.01$ vs. vehicle group. GLRX1, glutaredoxin; NeuN, neuronal nuclei.
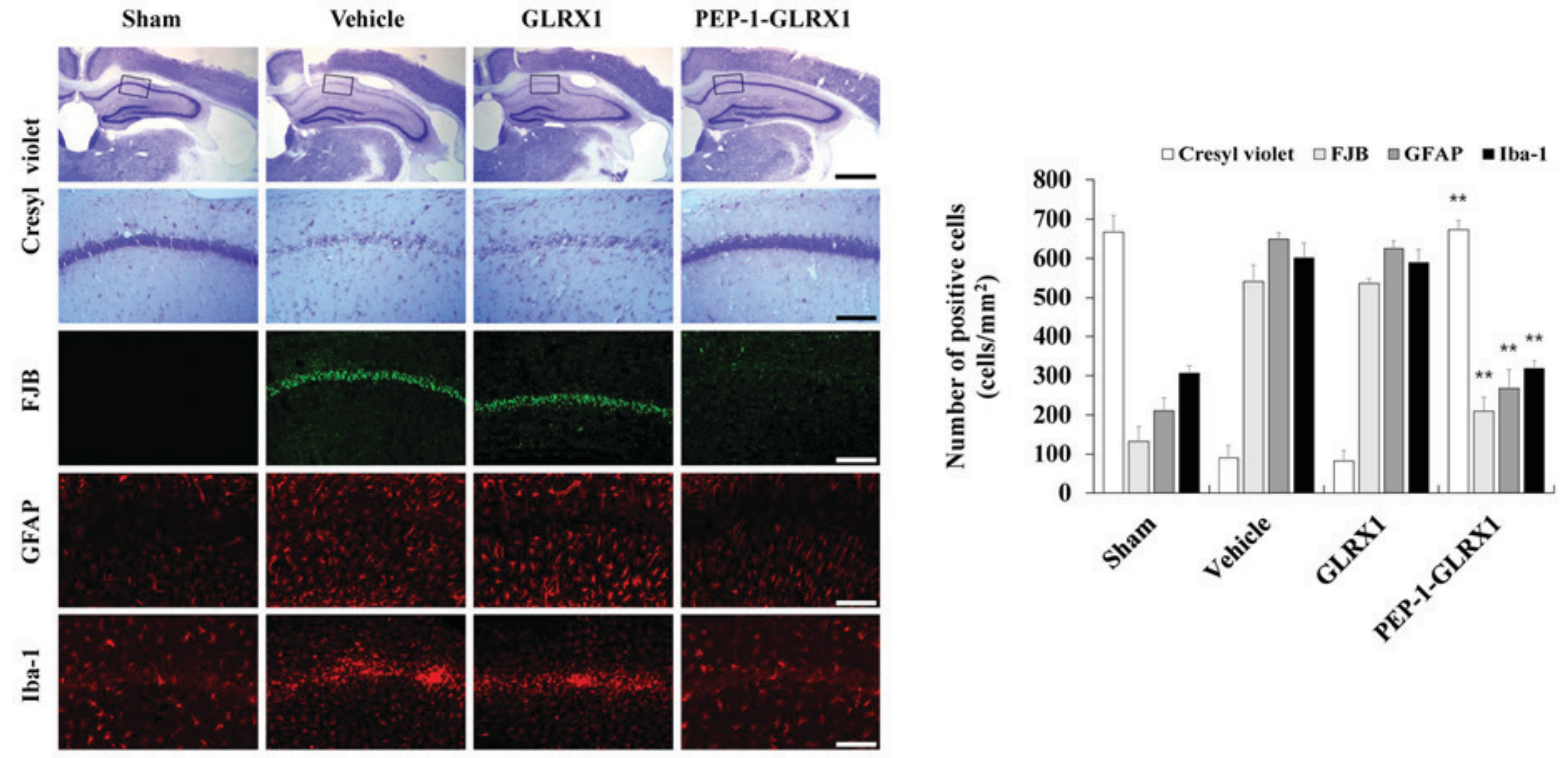

Figure 8. Effects of transduced PEP-1-GLRX1 protein against neuronal cell death in an animal model of ischemia. Neuroprotective effects of transduced PEP-1-GLRX1 protein were analyzed by CV,FJB, GFAP, and Iba-1 immunohistochemistry in the Cornu Ammonis 1 region of each group. Immunohistochemistry was performed in each of the control sham-, vehicle-, control GLRX1-, and PEP-1-GLRX1-treated groups 7 days following ischemia-reperfusion. Scale bars, $50 \mu \mathrm{m}$ (FJB, GFAP, Iba-1 and bottom CV panel) and $400 \mu \mathrm{m}$ (top CV panel). ${ }^{* *} \mathrm{P}<0.01$ vs. vehicle group. GLRX1, glutaredoxin; CV, cresyl violet; FJB, Fluoro-Jade B; GFAP, glial fibrillary acidic protein; Iba-1, ionized calcium-binding adapter molecule 1.

restricted due to their inability to transduce into cells. PTDs, additionally termed CPPs, are small peptides consisting of 10 to 16 basic amino acids which transduce the plasma membrane either alone or combined with various macromolecules including proteins, without the aid of a special receptor (33). The present study used a PEP-1 peptide PTD, which has the ability to deliver a variety of proteins into cells and tissues including the brain $(34,35)$. Even though numerous studies demonstrate that PEP-1 fused proteins transduce into cells and cross the BBB, the exact transduction mechanism is not yet fully understood.

ROS, including the superoxide anion $\left(\cdot \mathrm{O}^{2-}\right)$, hydroxyl radicals $(\cdot \mathrm{OH})$ and $\mathrm{H}_{2} \mathrm{O}_{2}$ are generated by oxidative stress and lead to destruction of macromolecules including proteins, lipids, and DNA (36). ROS are associated with various diseases including ischemia, diabetes mellitus, Parkinson's and Alzheimer's disease (37). The present study examined whether PEP-1-GLRX1 suppressed the $\mathrm{H}_{2} \mathrm{O}_{2}$-induced cell damage and elevated cellular ROS levels. $\mathrm{H}_{2} \mathrm{O}_{2}$-induced cell death was significantly decreased by PEP-1-GLRX1. Additionally, PEP-1-GLRX1 significantly inhibited intracellular $\mathrm{H}_{2} \mathrm{O}_{2}$-induced $\mathrm{ROS}$ production levels, which indicated that PEP-1-GLRX1 protected against $\mathrm{H}_{2} \mathrm{O}_{2}$-induced cell death by inhibiting intracellular ROS generation. These results are consistent with other studies in which overexpressed GLRX1 protein protects $\mathrm{H} 9 \mathrm{c} 2$ cells against $\mathrm{H}_{2} \mathrm{O}_{2}$ toxicity $(38,39)$.

Previous studies have revealed that $\mathrm{H}_{2} \mathrm{O}_{2}$ is the primary oxidizing agent which induces neuronal cell death by activation of Akt and MAPK signaling pathways, including JNK, ERK and p38 $(40,41)$. Conversely, other studies have indicated that activation of Akt and MAPKs by $\mathrm{H}_{2} \mathrm{O}_{2}$ appears to regulate 
distinct cellular responses including cell survival in different cell types (42-44). The present study investigated whether transduced PEP-1-GLRX1 protein inhibited the activation of Akt and MAPK signaling induced by $\mathrm{H}_{2} \mathrm{O}_{2}$. Transduced PEP-1-GLRX1 protein markedly inhibited phosphorylation of Akt and MAPK signaling in the $\mathrm{H}_{2} \mathrm{O}_{2}$ treated cells. A previous study suggested that GLRX1 protein inhibits oxidative stress through the regulation of Akt and MAPK signaling pathways (45). Kwon et al (41) demonstrated that Lonicera japonica THUNB (LJ) markedly inhibits the activation of Akt and MAPKs, suggesting that LJ prevents $\mathrm{H}_{2} \mathrm{O}_{2}$-induced apoptosis in $\mathrm{SH}-\mathrm{SY} 5 \mathrm{Y}$ cells by inhibition of the activation of Akt and MAPKs (41). Studies have additionally demonstrated that Akt and MAPKs are important in neuronal apoptosis in response to environmental stresses and apoptotic agents $(46,47)$. The results of the present study are consistent with reports that PEP-1-GLRX1 inhibits oxidative stress-induced HT-22 cell death by suppressing the activation of Akt and MPAK signaling.

Oxidative stress is highly associated with apoptotic signaling pathways and p53 is known to be a key regulator of apoptosis in neurons following ischemic injury (48-51). PEP-1-GLRX1 protein significantly reduced activation of p53 expression levels in a dose-dependent manner. Control GLRX1 did not affect the activation of p53 expression levels. Furthermore, the present study examined the effects of transduced PEP-1-GLRX1 protein against $\mathrm{H}_{2} \mathrm{O}_{2}$-induced alterations in $\mathrm{Bcl}-2$, $\mathrm{Bax}$ and pro-caspase-9 expression levels in addition to $\mathrm{H}_{2} \mathrm{O}_{2}$-induced DNA damage, as these proteins and DNA damage are known to be primary markers of apoptotic pathways $(52,53)$. Transduced PEP-1-GLRX1 protein significantly increased Bcl-2 and pro-caspase-9 expression levels compared with $\mathrm{H}_{2} \mathrm{O}_{2}$ treated cells. Conversely, Bax expression levels were markedly reduced. However, Bcl-2, Bax, and pro-caspase-9 expression levels did not alter in the control GLRX1 protein treated cells. In addition, TUNEL staining and 8-OHdG fluorescence staining were performed, which are well-known markers of DNA oxidation, in order to assess DNA damage (39). The results demonstrated that PEP-1-GLRX1 protected against $\mathrm{H}_{2} \mathrm{O}_{2}$-induced DNA damage in HT-22 cells, indicating that $\mathrm{H}_{2} \mathrm{O}_{2}$-induced neuronal cell death is markedly inhibited by transduced PEP-1-GLRX1 protein via regulation of apoptotic signaling pathways.

Although the exact mechanism of ischemic injury is not known, intracellular oxidative stress is considered to be one of the primary factors resulting in neurodegeneration including stroke and ischemia $(28,54)$. To investigate the function of PEP-1-GLRX1 against ischemic injury, the present study used a gerbil ischemia-reperfusion model. First, immunohistochemical staining was performed on hippocampal neuronal cells in the CA1 region to examine whether the PEP-1-GLRX1 fusion protein transduced into the $\mathrm{CA} 1$ region across the $\mathrm{BBB}$ in an animal model of ischemia. Crossing the BBB is a necessary step for therapeutic proteins to treat neuronal diseases as the majority of proteins cannot easily cross the BBB. Using His and NeuN staining, it was demonstrated that PEP-1-GLRX1 protein transduced into the $\mathrm{CA} 1$ region by crossing the $\mathrm{BBB}$, and markedly protected against neuronal cell death in an animal model of ischemia. To verify the neuronal damage, $\mathrm{CV}$ and F-JB staining were conducted, which are known to be sensitive markers for neuronal damage. As presented by CV and F-JB staining, PEP-1-GLRX1 protected against neuronal damage in the CA1 region, whereas the control GLRX1 protein did not affect the neuronal damage, which indicated that PEP-1-GLRX1 protected against ischemic injury in the animal model. These results are consistent with the author's previous reports, where it was demonstrated that cell permeable PTD proteins have a protective effect against neuronal cell death in the hippocampal CA1 region $(20,22)$.

Microglial activation is a primary cause of degenerative brain diseases and astrocytes significantly affect the survival of neuronal cells during brain damage including ischemia. Therefore, the activation of microglial and astrocytes are used as markers for the detection of ischemic neuronal injury $(55,56)$. Using Iba-1 and GFAP staining, which are microglia and astrocytes markers, the present study determined the effects of PEP-1-GLRX1 protein against microglial and astrocyte activation in an animal model of ischemia. PEP-1-GLRX1 protein significantly reduced the levels of Iba- 1 and GFAP immunoreactive cells in the animal model. The control GLRX1 protein treated group did not demonstrate the same activation of microglia and astrocytes compared with the vehicle-treated group. Although the exact mechanisms need to be examined to develop therapeutic treatments for ischemic injury using this protein, it was demonstrated that PEP-1-GLRX1 protein has neuroprotective effects on neuronal cell death in an ischemic animal model and this fusion protein may be a potential therapeutic agent for various neuronal diseases associated with to oxidative stress.

In conclusion, cell permeable PEP-1-GLRX1 protein was constructed and it was demonstrated that PEP-1-GLRX1 protein efficiently transduced into HT-22 cells and inhibited intracellular ROS production, and inhibited activation of the Akt, MAPK, and apoptotic signaling pathways. In an ischemic animal model, PEP-1-GLRX1 protein transduced into the animal brain following crossing the BBB and revealed strong neuroprotective effects against ischemic injury, suggesting that PEP-1-GLRX1 may have potential applications for treating ischemic injury and neuronal diseases.

\section{Acknowledgements}

Not applicable.

\section{Funding}

The present study was supported by a Priority Research Centers Program (grant no. 2009-0093812) and Mid-Career Researcher Program (grant no. 2016R1A2B4008356) through the National Research Foundation of Korea funded by the Ministry of Education, and Ministry of Science, ICT \& Future Planning.

\section{Availability of data and materials}

The analyzed datasets generated during the study are available from the corresponding author on reasonable request.

\section{Author's contributions}

EJR, DWK and MJS designed the research and experiments. HSJ, JHP, SBC, CHL, HJY, EJY and YJC contributed the 
reagents and analytic tools and assisted with the analysis and interpretation of the data. DSK, EJS and OS performed the cell and animal experiments. KWL, SWC, YJC, KHH and JP analyzed and interpreted the data. WSE and SYC designed the study and wrote the manuscript.

\section{Ethics approval and consent to participate}

All experimental procedures involving animals and their care conformed to the Guide for the Care and Use of Laboratory Animals of the National Veterinary Research \& Quarantine Service of Korea and were approved by the Institutional Animal Care and Use Committee of Soonchunhyang University (Cheonan-Si, Korea; SCH16-0024).

\section{Consent for publication}

Not applicable.

\section{Competing Interests}

The authors declare that they have no competing interests.

\section{References}

1. Kirkinezos IG and Moraes CT: Reactive oxygen species and mitochondrial diseases. Semin Cell Dev Biol 12: 449-457, 2001.

2. Matés JM: Effects of antioxidant enzymes in the molecular control of reactive oxygen species toxicology. Toxicology 153: 83-104, 2000.

3. Rice ME, Forman RE, Chen BT, Avshalumov MV, Cragg SJ and Drew KL: Brain antioxidant regulation in mammals and anoxia-tolerant reptiles: Balanced for neuroprotection and neuromodulation. Comp Biochem Physiol C Toxicol Phamacol 133. 515-525, 2002

4. Poljsak B, Šuput D and Milisav I: Achieving the balance between ROS and antioxidants: When to use the synthetic antioxidants. Oxid Med Cell Longev 2013: 956792, 2013.

5. Son Y, Cheong YK, Kim NH, Chung HT, Kang DG and Pae HO: Mitogen-activated protein kinases and reactive oxygen species: How can ROS activate MAPK pathways? J Signal Transduct 2011: 792639, 2011.

6. Saeed U, Durgadoss L, Valli RK, Joshi DC, Joshi PG and Ravindranath V: Knockdown of cytosolic Glutaredoxin 1 leads to loss of mitochondrial membrane potential: Implication in neurodegenerative diseases. PLoS One 3: e2459, 2008.

7. Sanderson TH, Reynolds CA, Kumar R, Przyklenk K and Hüttemann M: Molecular mechanisms of ischemia-reperfusion injury in brain: Pivotal role of the mitochondrial membrane potential in reactive oxygen species generation. Nol Neurobiol 47: 9-23, 2013

8. Jao SC, English Ospina SM, Berdis AJ, Starke DW, Post CB and Mieyal JJ: Computational and mutational analysis of human glutaredoxin (thioltransferase): Probing the molecular basis of the low pKa of cysteine 22 and its role in catalysis. Biochemistry 45: 4785-4796, 2006.

9. Okuda M, Inoue N, Azumi H, Seno T, Sumi Y, Hirata KI, Kawashima S, Hayashi Y, Itoh H, Yodoi J and Yokoyama M: Expression of glutaredoxin in human coronary arteries: Its potential role in antioxidant protection against atherosclerosis. Arterioscler Thromb Vasc Biol 21: 1483-1487, 2001.

10. Pai HV, Starke DW, Lesnefsky EJ, Hoppel CL and Mieyal JJ: What is the functional significance of the unique location of glutaredoxin 1 (GRx1) in the intermembrane space of mitochondria? Antioxid Redox Signal 9: 2027-2033, 2007.

11. Peltoniemi M, Kaarteenaho-Wiik R, Säily M, Sormunen R, Pääkkö P, Holmgren A, Soini Y and Kinnula VL: Expression of glutaredoxin is highly cell specific in human lung and is decreased by transforming growth factor-beta in vitro and in interstitial lung diseases in vivo. Hum Pathol 35: 1000-1007, 2004.
12. Cater MA, Materia S, Xiao Z, Wolyniec K, Ackland SM, Yap YW, Cheung NS and La Fontaine S: Glutaredoxin1 protects neuronal cells from copper-induced toxicity. Biometals 27: 661-672, 2014

13. El-Andaloussi S, Holm T and Langel U: Cell-penetrating peptides: Mechanisms and applications. Curr Pharm Des 11: 3597-3611, 2005.

14. Beerens AM, Al Hadithy AF, Rots MG and Haisma HJ: Protein transduction domains and their utility in gene therapy. Curr Gene Ther 3: 486-494, 2003.

15. Morris MC, Depollier J, Mery J, Heitz F and Divita G: A peptide carrier for the delivery of biologically active proteins into mammalian cells. Nat Biotechonol 19: 1173-1176, 2001.

16. Ahn EH, Kim DW, Shin MJ, Kim HR, Kim SM, Woo SJ, Eom SA, Jo HS, Kim DS, Cho SW, et al: PEP-1-PEA-15 protects against toxin-induced neuronal damage in a mouse model of Parkinson's disease. Biochim Biophys Acta 1840: 1686-1700, 2014.

17. Kim DW, Lee SH, Shin MJ, Kim K, Ku SK, Youn JK, Cho SB, Park JH, Lee CH, Son O, et al: PEP-1-FK506BP inhibits alkali burn-induced corneal inflammation on the rat model of corneal alkali injury. BMB Rep 48: 618-623, 2015.

18. Kim HR, Kim DW, Jo HS, Cho SB, Park JH, Lee CH, Choi YJ, Yeo EJ, Park SY, Kim ST, et al: Tat-biliverdin reductase A inhibits inflammatory response by regulation of MAPK and NF- $\kappa$ B pathways in Raw 264.7 cells and edema mouse model. Mol Immunol 63: 355-366, 2015.

19. Kim MJ, Park M, Kim DW, Shin MJ, Son O, Jo HS, Yeo HJ, Cho SB, Park JH, Lee CH, et al: Transduced PEP-1-PON1 proteins regulate microglial activation and dopaminergic neuronal death in a Parkinson's disease model. Biomaterials 64: 45-56, 2015.

20. Kim YN, Jung HY, Eum WS, Kim DW, Shin MJ, Ahn EH, Kim SJ, Lee CH, Yong JI, Ryu EJ, et al: Neuroprotective effects of PEP-1-carbonyl reductase 1 against oxidative-stress-induced ischemic neuronal cell damage. Free Radic Biol Med 69: 181-196, 2014.

21. Jo HS, Yeo HJ, Cha HJ, Kim SJ, Cho SB, Park JH, Lee CH, Yeo EJ, Choi YJ, Eum WS and Choi SY: Transduced Tat-DJ-1 protein inhibits cytokines-induced pancreatic RINm5F cell death. BMB Rep 49: 297-302, 2016.

22. Shin MJ, Kim DW, Jo HS, Cho SB, Park JH, Lee CH, Yeo EJ, Choi YJ, Kim JA, Hwang JS, et al: Tat-PRAS40 prevent hippocampal HT-22 cell death and oxidative stress induced animal brain ischemic insults. Free Radic Biol Med 97: 250-262, 2016.

23. Bradford MM: A rapid and sensitive method for the quantitation of microgram quantities of protein utilizing the principle of protein-dye binding. Anal Biochem 72: 248-254, 1976.

24. An SY, Youn GS, Kim H, Choi SY and Park J: Celastrol suppresses expression of adhesion molecules and chemokines by inhibiting JNK-STAT1/NF- $\kappa$ B activation in poly(I:C)-stimulated astrocytes. BMB Rep 50: 25-30, 2017.

25. Jo HS, Kim DS, Ahn EH, Kim DW, Shim MJ, Cho SB, Park JH, Lee CH, Yeo EJ, Choi YJ, et al: Protective effects of Tat-NQO1 against oxidative stress-induced HT-22 cell damage, and ischemic injury in animals. BMB Rep 49: 617-622, 2016.

26. Sohn EJ, Shin MJ, Kim DW, Son O, Jo HS, Cho SB, Park JH, Lee CH, Yeo EJ, Choi YJ, et al: PEP-1-GSTpi protein enhanced hippocampal neuronal cell survival after oxidative damage. BMB Rep 49: 382-387, 2016.

27. Niizuma K, Yoshioka H, Chen H, Kim GS, Jung JE, Katsu M, Okami N and Chan PH: Mitochondrial and apoptotic neuronal death signaling pathways in cerebral ischemia. Biochim Biophys Acta 1802: 92-99, 2010.

28. Pradeep H, Diya JB, Shashikumar S and Rajanikant GK: Oxidative stress-assassin behind the ischemic stroke. Folia Neuropathol 50: 219-230, 2012.

29. Yu JT, Lee CH, Yoo KY, Choi JH, Li H, Park OK, Yan B, Hwang IK, Kwon YG, Kim YM, et al: Maintenance of anti-inflammatory cytokines and reduction of glial activation in the ischemic hippocampal CA1 region preconditioned with lipopolysaccharide. J Neurol Sci 296: 69-78, 2010.

30. Bachschmid MM, Xu S, Maitland-Toolan KA, Ho YS, Cohen RA and Matsui R: Attenuated cardiovascular hypertrophy and oxidant generation in response to angiotensin II infusion in glutaredoxin-1 knockout mice. Free Radic Biol Med 49: 1221-1229, 2010.

31. Murata H, Ihara Y, Nakamura H, Yodoi J, Sumikawa K and Kondo T: Glutaredoxin exerts an antiapoptotic effect by regulating the redox state of Akt. J Biol Chem 278: 50226-50233, 2003 . 
32. Akterin S, Cowburn RF, Miranda-Vizuete A, Jiménez A Bogdanovic N, Winblad B and Cedazo-Minguez A: Involvement of glutaredoxin-1 and thioredoxin-1 in beta-amyloid toxicity and Alzheimer's disease. Cell Death Differ 13: 1454-1465, 2006.

33. Joliot A and Prochiantz A: Transduction peptides: From technology to physiology. Nat Cell Biol 6: 189-196, 2004.

34. Dietz GP: Cell-penetrating peptide technology to deliver chaperones and associated factors in diseases and basic research. Curr Pharm Biotechnol 11: 167-174, 2010.

35. Popiel HA, Nagai Y, Fujikake N and Toda T: Protein transduction domain-mediated delivery of QBP1 suppresses polyglutamine-induced neurodegeneration in vivo. Mol Ther 15: 303-309, 2007.

36. Barrera G: Oxidative stress and lipid peroxidation products in cancer progression and therapy. ISRN Oncol 2012: 137289, 2012.

37. Emerit J, Edeas M and Bricaire F: Neurodegenerative diseases and oxidative stress. Biomed Pharmacother 58: 39-46, 2004.

38. Ho YS, Xiong Y, Ho DS, Gao J, Chua BH, Pai H and Mieyal JJ: Targeted disruption of the glutaredoxin 1 gene does not sensitize adult mice to tissue injury induced by ischemia/reperfusion and hyperoxia. Free Radic Biol Med 43: 1299-1312, 2007.

39. Valavanidis A, Vlachogianni T and Fiotakis C: 8-hydroxy-2'-deoxyguanosine (8-OHdG): A critical biomarker of oxidative stress and carcinogenesis. J Environ Sci Health C Environ Carcinog Ecotoxicol Rev 27: 120-139, 2009.

40. Lahair MM, Howe CJ, Rodriguez-Mora O, McCubrey JA and Franklin RA: Molecular pathways leading to oxidative stress-induced phosphorylation of Akt. Antioxid Redox signal 8: $1749-1756,2006$

41. Kwon SH, Hong SI, Kim JA, Jung YH, Kim SY, Kim HC, Lee SY and Jang CG: The neuroprotective effects of Lonicera japonica THUNB. Against hydrogen peroxide-induced apoptosis via phosphorylation of MAPKs and PI3K/Akt in SH-SY5Y cells. Food Chem Toxicol 49: 1011-1019, 2011.

42. Hwang SL and Yen GC: Modulation of Akt, JNK, and p38 activation is involved in citrus flavonoid-mediated cytoprotection of PC12 cells challenged by hydrogen peroxide. J Agric Food Chem 57: 2576-2582, 2009

43. Yang $\mathrm{B}, \mathrm{Oo} \mathrm{TN}$ and Rizzo V: Lipid rafts mediate $\mathrm{H} 2 \mathrm{O} 2$ prosurvival effects in cultured endothelial cells. FASEB J 20: 1501-1503, 2006.

44. Ruffels J, Griffin M and Dickenson JM: Activation of ERK1/2, JNK and PKB by hydrogen peroxide in human SH-SY5Y neuroblastoma cells: Role of ERK1/2 in H2O2-induced cell death. Eur J Pharmacol 483: 163-173, 2004.
45. Liu X, Jann J, Xavier C and Wu H: Glutaredoxin 1 (Grx1) protects human retinal pigment epithelial cells from oxidative damage by preventing AKT glutathionylation. Invest Ophtalmol Vis Sci 56: 2821-2832, 2015

46. Fulda S, Gorman AM, Hori O and Samali A: Cellular stress responses: Cell survival and cell death. Int J Cell Biol 2010: 214074, 2010.

47. Villegas SN, Njaine B, Linden R and Carri NG: Glial-derived neurotrophic factor (GDNF) prevents ethanol $(\mathrm{EtOH})$ induced B92 glial cell death by both PI3K/AKT and MEK/ERK signaling pathways. Brain Res Bull 71: 116-126, 2006.

48. Reddy PH: Role of mitochondria in neurodegenerative diseases: Mitochondria as a therapeutic target in Alzheimer's disease. CNS Spectr 14 (8 Suppl 7): 8-13; discussion 16-8, 2009.

49. Gupta S, Kass GE, Szeqezdi E and Joseph B: The mitochondrial death pathway: A promising therapeutic target in diseases. J Cell Mol Med 13: 1004-1033, 2009

50. Gu ZT, Wang H, Li L, Liu YS, Deng XB, Huo SF, Yuan FF, Liu ZF, Tong HS and Su L: Heat stress induces apoptosis through transcription-independent p53-mediated mitochondrial pathways in human umbilical vein endothelial cell. Sci Rep 4: 4469, 2014.

51. Niizuma K, Endo H and Chan PH: Oxidative stress and mitochondrial dysfunction as determinants of ischemic neuronal death and survival. J Neurochem 1 (109 Suppl): 133-138, 2009.

52. Zhang S, Ong CN and Shen HM: Involvement of proapoptotic Bcl-2 family members in parthenolide-induced mitochondrial dysfunction and apoptosis. Cancer Lett 211: 175-188, 2004.

53. Würstle ML, Laussmann MA and Rehm M: The central role of initiator caspase-9 in apoptosis signal transduction and the regulation of its activation and activity on the apoptosome. Exp Cell Res 318: 1213-1220, 2012.

54. Kalogeris T, Baines CP, Krenz M and Korthuis RJ: Cell biology of ischemia/reperfusion injury. Int Rev Cell Mol Biol 298: 229-317, 2012.

55. Ito D, Tanaka K, Suzuki S, Dembo T and Fukuuchi Y: Enhanced expression of Iba1, ionized calcium-binding adapter molecule 1 , after transient focal cerebral ischemia in rat brain. Stroke 32: $1208-1215,2001$

56. Chen Y and Swanson RA: Astrocytes and brain Injury. J Cereb Blood Flow Metab 23: 137-149, 2003. 